\title{
Nuclear start-up procedures revised in wake of failures
}

\section{Washington}

THE US Department of Energy (DoE) announced last week that it would try an entirely new approach to restarting its defence production reactors at the Savannah River Plant in South Carolina. The decision comes in the wake of revelations of continued safety problems at Savannah River and other DoE plants involved in the production of nuclear material for weapons. DoE Secretary John Herrington says the problems are coming to light because of heightened activity by environmental safety and health officials within the department, but critics say DoE is only reacting to a crisis situation, and there is no guarantee that the department's current interest in safety will translate to a new attitude within the department.

DoE's safety concerns have focused most recently on the problems associated with restarting one of the three heavy water reactors at Savannah River used to produce tritium. The Savannah River reactors are each more than thirty years old, and are showing signs of age. The plant has been operated by E. I. du Pont de Nemours and Company since it was built. But Du Pont has declined to renew its contract, and its role will be taken over by Westinghouse next April.

The $P$ reactor was shut down last April to evaluate and upgrade the seismic capability of safety systems. Since the shutdown was expected to be brief, tritium that was being produced was left in the reactor. But the restart was delayed until 7 August and when operators attempted to restart the reactor they failed to take into account the decay of tritium to helium-3, a neutron absorber that can "poison" the reactor.

Operators could not understand why the control rods had to be removed so far in order to achieve criticality, and subsequent analysis showed that there was a potentially dangerous amount of reactivity that could not be accounted for. What upset DoE was that the operators did not stop the start-up procedure to find out what was wrong.

A build-up of xenon led to the reactor being shut down on 9 August, but it was restarted again that same night. On 10 August, an unexplained 2 per cent jump in power occurred, but operators decided to proceed with the start-up procedure. The reactor was finally shut down on 17 August.

Although DoE does not believe that the incident represented a danger to the public, the department was nonetheless chastened by these events. A memo written by Richard Starostecki, deputy assistant secretary for safety, health and quality assurance, criticized the attitude of the plant operators as being "a prelude to disaster". He wrote that "the operating staff and advisors, knowing that they did not understand what was going on inside failed to put the reactor in a safe, known condition (shutdown) while they investigated, did not vigorously investigate, and THEY DIDN'T CARE!" (emphasis in memo).

Speaking at a press conference last week, DoE deputy secretary Joseph Salgado described the department as "in transition". He says DoE is moving into a period where safety will receive renewed emphasis, adding that the department is watching its contractors much more closely.

It will be some time before new safety systems can be installed in the $\mathrm{P}$ reactor, so DoE is now planning to start the $K$ reactor by the end of the year. The $\mathrm{K}$ reactor has recently had a fourth emergency core cooling system installed, and is now undergoing seismic tests. For the first time, a phased start-up procedure will be used. Specific targets in the start-up process will have to be met to the satisfaction of DoE before the process will be permitted to continue. If all goes well, DoE hopes to have the reactor operating

\section{Peaceful approach to Northwest Passage}

\section{Washington}

IN the first test of an Arctic agreement signed by the United States and Canada in January, the US administration has asked for permission for a US vessel to pass through the disputed Northwest Passage. The agreement is a compromise that dictates the United States must ask to enter Arctic waters claimed by Canada even though it refuses to acknowledge Canadian sovereignty over them.

The vessel involved is the US Coast Guard icebreaker Polar Star, which is retreating into Canadian-claimed waters after failing to break through unexpectedly heavy ice off the coast of Alaska. The vessel is the sister ship of the Polar Sea whose unannounced transit through the Northwest Passage in 1985 outraged Canadians and triggered an international dispute (see Nature 333, 733; 1988).

The United States, backed by NATO countries, wished to regard the Northwest Passage as international waters, partly because of their military importance for the movement of submarines between the Atlantic and Pacific Oceans and partly because granting sovereignty there would lead to similar claims on waterways elsewhere in the world. The Soviet by January of next year.

The United States currently has no plant capable of producing tritium for its nuclear weapons arsenal, but DoE officials are confident that one of the Savannah River reactors can be brought back on line before the situation becomes critical. DoE has denied that it may be necessary to 'cannibalize' weapons to obtain tritium.

Although DoE has been critical of Du Pont's operation of Savannah River, there are those who feel that DoE must ultimately be held accountable for the problems at its facilities. At a hearing at the end of last month Representative Mike Synar (Democrat, Oklahoma), chairman of the environment, energy and natural resources subcommittee of the Committee on Government Operations spoke of an "attitude of indifference to safety and an unwillingness by DoE, even at the highest levels, to assume control of its own facility". For its part, Du Pont chairman Richard Heckert has rejected charges that his company has operated the plants in an unsafe manner, pointing to a 38-year safety record.

Savannah River is not the only DoE weapons facility with safety problems. DoE officials last week announced the shut-down of a key portion of its Rocky Flats materials processing plant in Colorado because of poor safety procedures, and another fuel processing facility at Fernald, Ohio, is currently in the midst of a labour dispute.

Joseph Palca

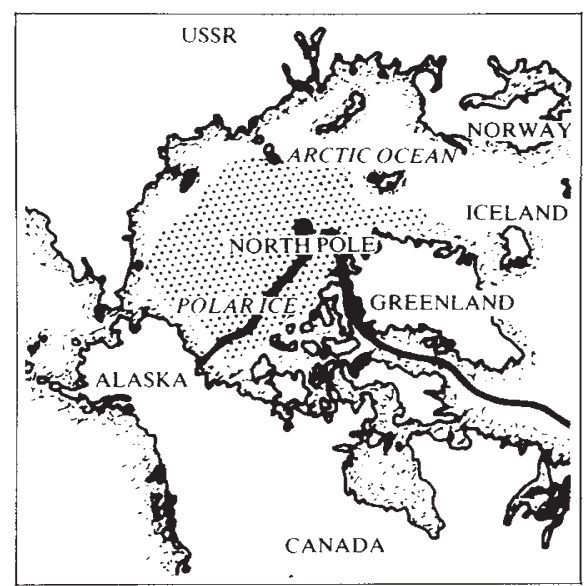

The Northwest Passage winds among Canada's islands from the Prince of Wales Strait to Lancaster Sound.

Union supported Canada's view as it claims similar territorial rights in its own Arctic territories.

The dispute made Canada aware that it had no way to police the Arctic territories and led to plans for a massive all-year capable ice breaker and for a fleet of British or French nuclear submarines capable of penetrating beneath the ice.

Alun Anderson 